\title{
THE IMPACT OF COUPLING THERMOELASTICITY EQUATIONS ON SETTLEMENT OF STRUCTURES ON FROZEN SOIL
}

\author{
Roman N. Stepanov, Fedor B. Kiselyov, Filipp V. Sergeyev \\ National Research Moscow State University of Civil Engineering, Moscow, RUSSIA
}

\begin{abstract}
This paper seeks to propose a numeric model for the determination of structure's settlement on frozen soil. The settlement is driven by the dead weight of the soil, weight of the erected building and thawing of the soil underneath the building due to its heating. A benchmark task was solved both in coupled and uncoupled problem settings. A special analysis is dedicated to the impact of thermoelasticity equations being coupled or independent.
\end{abstract}

Key words: multiyear frozen soils, thermoelasticity, structure settlement, thawing

\section{ВЛИЯНИЕ СВЯЗАННОСТИ УРАВНЕНИЙ ТЕРМОУПРУГОСТИ НА ОСАДКУ СООРУЖЕНИЯ НА МЕРЗЛОМ ГРУНТЕ}

\author{
Р.Н. Степанов, Ф.Б. Киселёв, Ф.В. Сергеев \\ Национальный исследовательский Московский государственный строительный университет, \\ г. Москва, РОССИЯ
}

\begin{abstract}
Аннотация: В данной работе предложена численная модель для определения осадки сооружения на мерзлом грунте. Осадка происходит за счет действия собственного веса грунта, веса возведенного сооружения и за счет оттаивания грунта под фундаментом сооружения из-за его разогрева. Была решена модельная задача в связанной и несвязанной постановке. Проанализировано влияние эффекта связанности уравнений термоупругости.
\end{abstract}

Ключевые слова: мнногетнемерзлые грунты, термоупругость, осадка соружения, процесс оттаивания

\section{PROBLEM SETTING}

Expression [1] presents thermoelasticity equations linearized around the initial temperature $T_{0}$ of the undeformed state. These equations describe soil deformation driven by the temperature gradient $T$ and bulk forces. By generalizing the equations for the case of partially frozen soil, we obtain the following system:

$$
\left\{\begin{array}{l}
\frac{\partial}{\partial x_{j}}\left(C_{i j k l}^{t h(f)} \frac{\partial u_{k}}{\partial x_{l}}\right)=3 \alpha^{t h(f)} K^{t h(f)} \frac{\partial\left(T-T_{0}\right)}{\partial x_{i}}-\rho F_{i} \\
\frac{\partial}{\partial x_{i}}\left(\lambda_{i j}^{t h(f)} \frac{\partial\left(T-T_{0}\right)}{\partial x_{j}}\right)+q_{V}=3 \alpha^{t h(f)} K^{t h(f)} T_{0} \frac{\partial}{\partial t}\left(\frac{\partial u_{i}}{\partial x_{i}}\right)+ \\
+\rho c^{t h(f)} \frac{\partial}{\partial t}\left(T-T_{0}\right)
\end{array}\right.
$$

where

$$
\begin{aligned}
& C_{i j k l}^{t h(f)}=\frac{v^{t h(f)} E^{t h(f)}}{\left(1+v^{t h(f)}\right)\left(1-2 v^{t h(f)}\right)} \delta_{i j} \delta_{k l}+ \\
& +\frac{E^{t h(f)}}{2\left(1+v^{t h(f)}\right)}\left(\delta_{i k} \delta_{j l}+\delta_{i l} \delta_{j k}\right)
\end{aligned}
$$

- elastic modulus tensor of frozen or thawed soil; $\underset{\sim}{{\underset{\sim}{t h(f)}}^{t}}$ - tensor permeability coefficient of thawed or frozen soil; $\alpha^{\text {th }(f)}$ - linear thermal expansion coefficient of thawed or frozen soil; $c^{t h(f)}-$ specific heat capacity of thawed or frozen soil; 


$$
K^{t h(f)}=\frac{E^{t h(f)}}{3\left(1-2 v^{t h(f)}\right)}
$$

- cubical expansion (compression) coefficient of thawed or frozen soil; $q_{V}$ - power of inner heat sources in a volumetric unit; $\rho$ - density of dry soil. The target values of these equations are soil displacements $\vec{u}$ and temperature $T$.

Based on the papers [2-4], the analytical dependency (2) for the heat capacity coefficient takes account of ice-water phase transitions when crossing the ground thawing temperature:

$$
c^{t h(f)}=c^{(f)}+L_{0} \frac{\partial W_{W}}{\partial T},
$$

where $L_{0}=335 * 10^{6} \mathrm{~J} / \mathrm{m}^{3}$,

while the total content of the unfrozen water depends on the temperature and is given by the formula:

$$
W_{W}=k_{W} W_{p},
$$

where $W_{p}$ - humidity at the lower plastic limit of soil when rolled into threads, $W_{W}$ - soil humidity due to unfrozen water, $K_{W}$ - unfrozen water content coefficient identified for various temperatures according to Table 3.1. in [5]. The analytical dependency established between the Young's modulus $E^{\text {th }(f)}$ and temperature and interpolating experimental data is presented in [6]. Analogous curves were constructed for Poisson's ratio $v^{\text {th }(f)}$ and thermal conductivity $\lambda^{\text {th }(f)}$ in [7]. The problem setting is finalized by standard initial and boundary conditions. The equations (1) of the task are coupled. They do not allow for the possibility to ascertain the thermal field independently without finding the soil deformations.

While accepting a simplified hypothesis that thermal field is independent from soil deformations, we can relax it and solve the equations independently one from the other: first, we determine the thermal field based on the heat propagation equation, and then identify structure's settlement via the Duhamel Neumanntype equation of equilibrium. In this case, the system of equations in question takes the following form:

$$
\left\{\begin{array}{l}
\frac{\partial}{\partial x_{j}}\left(C_{i j k l}^{t h(f)} \frac{\partial u_{k}}{\partial x_{l}}\right)=3 \alpha^{t h(f)} K^{t h(f)} \frac{\partial\left(T-T_{0}\right)}{\partial x_{i}}-\rho F_{i} \\
\frac{\partial}{\partial x_{i}}\left(\lambda_{i j}^{t h(f)} \frac{\partial\left(T-T_{0}\right)}{\partial x_{j}}\right)+q_{V}=\rho c^{t h(f)} \frac{\partial}{\partial t}\left(T-T_{0}\right) .
\end{array}\right.
$$

\section{NUMERICAL SOLUTION}

For solving the system (1), Euler's implicit method was applied for time discretization of the task $t^{n+1}=t^{n}+\Delta t$ :

$$
\left\{\begin{array}{l}
\frac{\partial}{\partial x_{j}}\left(C_{i j k l}^{t h(f)} \frac{\partial u_{k}^{n+1}}{\partial x_{l}}\right)- \\
-3 \alpha^{t h(f)} K^{t h(f)} \frac{\partial\left(T^{n+1}-T_{0}\right)}{\partial x_{i}}=-\rho F_{i} \\
\frac{\partial}{\partial x_{i}}\left(-3 \alpha^{t h(f)} K^{t h(f)} T_{0} \frac{u_{i}{ }^{n+1}}{\Delta t}+\lambda_{i j}^{t h(f)} \frac{\partial\left(T^{n+1}-T_{0}\right)}{\partial x_{j}}\right)- \\
-\frac{\rho c^{t h(f)}}{\Delta t}\left(T^{n+1}-T_{0}\right)= \\
=-3 \alpha^{t h(f)} K^{t h(f)} T_{0} \frac{u_{i}{ }^{n}}{\Delta t}-\frac{\rho c^{t h(f)}}{\Delta t}\left(T^{n}-T_{0}\right)-q_{V},
\end{array}\right.
$$

Where the superscript $n+1$ of the target $\mathrm{k}^{\text {th }}$ displacement vector component $u_{k}{ }^{n+1}$ as well as of the temperature $T^{n+1}$ means that the values of these functions were utilized till the $n+1^{\text {th }}$ time increment. This equation can be presented as a block matrix: 


$$
\left(\begin{array}{cc}
\frac{\partial}{\partial x_{j}}\left(C_{i j k l}^{t h(f)} \frac{\partial(\cdot)}{\partial x_{l}}\right) & -\frac{\partial}{\partial x_{i}}\left(3 \alpha^{t h(f)} K^{t h(f)}(\cdot)\right) \\
-\frac{\partial}{\partial x_{k}}\left(3 \alpha^{t h(f)} K^{t h(f)} T_{0} \frac{(\cdot)}{\Delta t}\right) & \frac{\partial}{\partial x_{i}}\left(\lambda_{i j}^{t h(f)} \frac{\partial(\cdot)}{\partial x_{j}}\right)-\frac{\rho c^{t h(f) n}}{\Delta t}(\cdot)
\end{array}\right)\left(\begin{array}{c}
u_{k}^{n+1} \\
T^{n+1}-T_{0}
\end{array}\right)=\left(\begin{array}{l}
\vec{f}_{1} \\
f_{2}
\end{array}\right)
$$

Where the vector of the right hand side is equal to

$$
\left(\begin{array}{l}
\vec{f}_{1} \\
f_{2}
\end{array}\right)=\left(\begin{array}{c}
-\rho F_{i} \\
-3 \alpha^{t h(f)} K^{t h(f)} T_{0} \frac{u_{i}^{n}}{\Delta t}-\frac{\rho c^{t h(f)}}{\Delta t}\left(T^{n}-T_{0}\right)-q_{V}
\end{array}\right) .
$$

The discretization of the spatial variables is accomplished by the method of finite elements and use of standard isoparametric brick-type finite elements. To find a solution, which is a column vector of variables

$$
\left(\begin{array}{c}
u_{k}^{n+1} \\
T^{n+1}-T_{0}
\end{array}\right)
$$

using Gaussian method for solving systems of linear algebraic equations proves sufficient. The problem's coefficients are temperature functions. Their value for the current time increment is calculated based on the solution to the problem found for the previous time increment. For this reason, an internal iteration process was introduced, so that the numeric and exact solutions would match at each time increment.

\section{BENCHMARK PROBLEM}

The problem of finding the building settlement on frozen soil makes use of the numeric model constructed earlier. The settlement is driven by the dead load of the soil, weight of the erected facility and soil thawing under the building's foundation due to its heating. The foundation without heat insulation is warmed up because the temperature inside the facility exceeds that of outside. The calculation performed for the model employs both coupled and independent equations. Figure 1 displays one fourth of the computational domain. The soil is modeled as a three-layer environment with thermomechanical constants, the values of which can be found in Table 1. Initial temperature distribution $T_{0}$ within the domain (see Figure 2) is considered at the first stage of the numeric algorithm employed when solving the thermal conductivity equation for a specific temperature and heat flow at the boundary of the domain. The upper horizontal boundary of the domain (soil surface) maintains the temperature $+2{ }^{0} \mathrm{C}$, while the lower horizontal boundary of the domain (foot of the multiyear frozen soil) keeps the temperature $-2{ }^{0} \mathrm{C}$. This temperature range suggests that the multiyear frozen soil commences $10 \mathrm{~m}$ below the earth surface. The second stage of the numeric algorithm solves the problem of heating the surface layer of soil under the foundation bed by the temperature $+20{ }^{0} \mathrm{C}$ applied continuously. The second stage starts after the construction has been completed and the structure has been commissioned. The calculation is performed till the temporal solution is found, which is assumed to be 30 years in this model. Figures 3-6 display the vertical displacement pattern and temperature pattern 30 years after the construction completion. The data in Figures 3 and 4 were obtained when solving the task in the coupled problem setting, while those of Figures 5 and 6 were derived from the solution in the uncoupled problem setting. The analysis of the obtained data brings about the conclusion that the benchmark problem features the soil thawing depth being equal to $15 \mathrm{~m}$ for the coupled problem setting and $14 \mathrm{~m}$ for the uncoupled problem setting. Relative differential settlement of the facility for the solution in the coupled problem setting is $17,5 \mathrm{~cm}$, while the same for the uncoupled task setting is $13 \mathrm{~cm}$. 


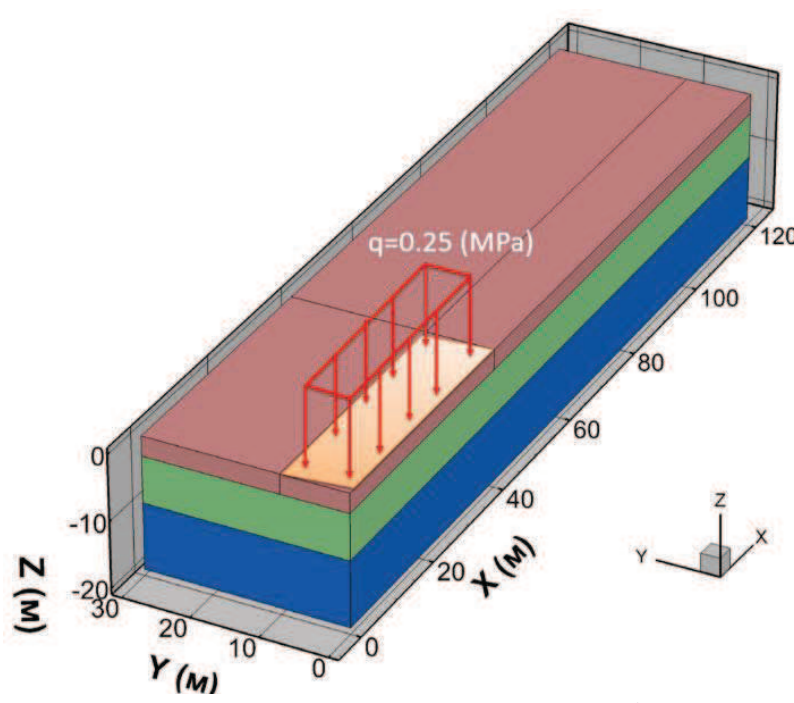

Figure 1. 1/4 of the computational domain, with distributed surface pressure applied.

The surface taken up by the structure is depicted in yellow.

Table 1. Thermomechanical constants of the model

\begin{tabular}{|c|c|c|c|}
\hline $\begin{array}{c}\text { Constants } \\
\text { of soil layer }\end{array}$ & $\begin{array}{c}\text { Crushed } \\
\text { stone or } \\
\text { grus fill } \\
\text { material }\end{array}$ & $\begin{array}{c}\text { Clayey } \\
\text { sand }\end{array}$ & $\begin{array}{c}\text { Grus with } \\
\text { clayey } \\
\text { sand fill } \\
\text { (multiyear } \\
\text { frozen) }\end{array}$ \\
\hline 1 & 2 & 3 & 4 \\
\hline $\begin{array}{c}\text { Soil depth, } \mathrm{m} \\
\text { Density } \rho, \\
\mathrm{kg} / \mathrm{m}^{3}\end{array}$ & 2220 & 2120 & 2360 \\
\hline $\begin{array}{c}\text { Deformation } \\
\text { modulus } \\
E^{\text {th }(f)} \\
\mathrm{mPa}\end{array}$ & 40 & 30.6 & 30 \\
\hline $\begin{array}{c}\text { Poisson } \\
\text { coefficient } \\
v^{\text {th }(f)}\end{array}$ & 0.4 & 0.4 & 0.4 \\
\hline $\begin{array}{c}\text { Specific heat } \\
\text { capacity } \\
c^{\text {th }(f)}, \\
\mathrm{J} /\left(\mathrm{kg} \cdot{ }^{\circ} \mathrm{C}\right)\end{array}$ & 918 & 1076.6 & 960 \\
\hline $\begin{array}{c}\mathrm{Heat} \\
\text { transmission } \\
\lambda^{\text {th }(f)}, \\
\mathrm{W} /\left(\mathrm{m} \cdot{ }^{0} \mathrm{C}\right)\end{array}$ & 1.8 & 1.74 & 1.48 \\
\hline
\end{tabular}

Volume 13, Issue 1, 2017

\begin{tabular}{|c|l|l|l|}
\hline 1 & 2 & 3 & 4 \\
\hline Linear & 0 & 0 & 0.0009 \\
thermal & & & \\
expansion & & & \\
coefficient & & & \\
$\alpha^{\text {th }(f),}$ & & & \\
$1 /{ }^{0} \mathrm{C}$ & & & \\
\hline
\end{tabular}

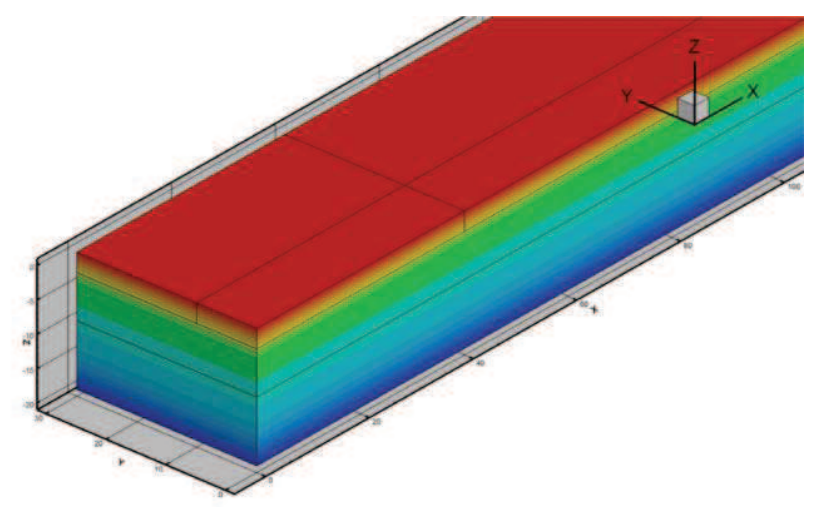

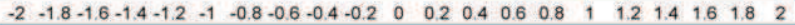

Figure 2. Initial temperature distribution across the computational domain, ${ }^{0} \mathrm{C}$.

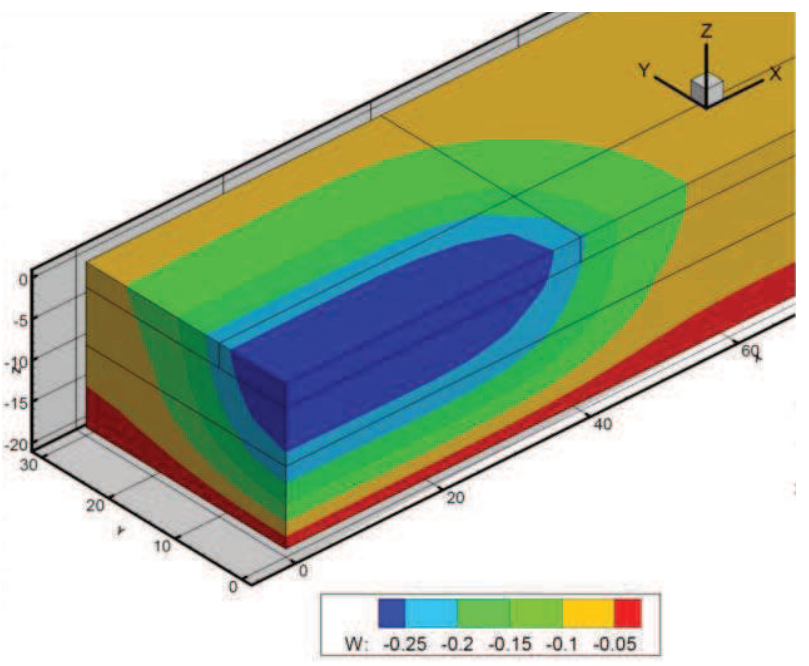

Figure 3. Vertical displacements $(m)$ in the soil 30 years after construction completion. Solution in the coupled problem setting. Relative settlement equal to $17.5 \mathrm{~cm}$. 


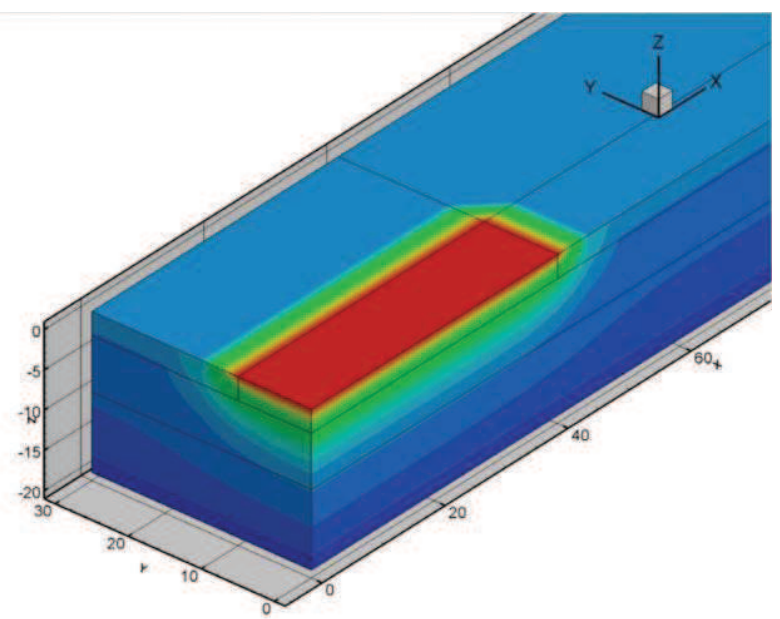

P: $-2-10012234456778991011121314151617181920$

Figure 4. Temperature distribution $\left({ }^{\circ} \mathrm{C}\right)$ in the soil 30 years after construction completion.

Solution in the coupled problem setting.

Thawing depth found to be $15 \mathrm{~m}$.

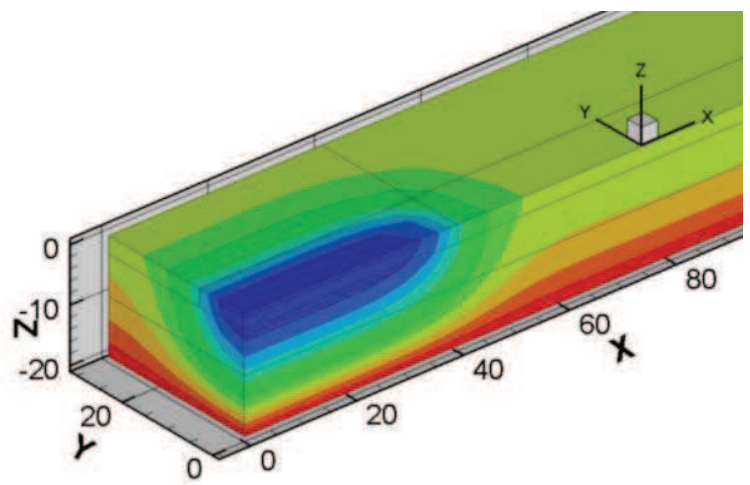

W: $-0.2-0.18-0.16-0.14-0.12-0.1-0.08-0.06-0.04-0.02$

Figure 5. Vertical displacements $(m)$ in the soil 30 years after construction completion. Solution in the uncoupled problem setting. Relative settlement of the structure found to be $13 \mathrm{~cm}$.

\section{CONCLUSION}

The analysis of the results obtained gives rise to the following conclusions. If taken account of, the thermomechanical term

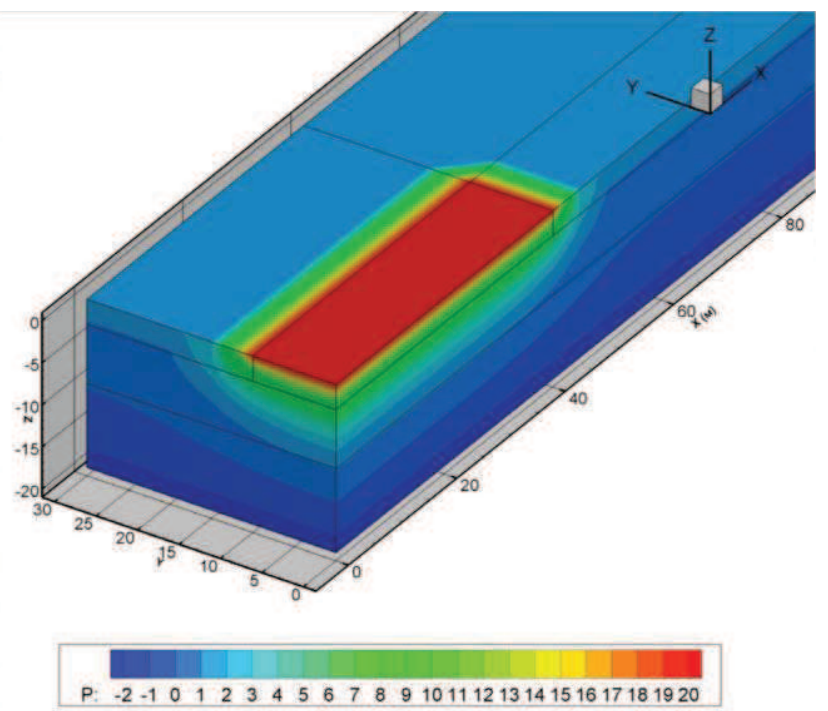

Figure 6. Temperature distribution $\left({ }^{\circ} C\right)$ in the soil 30 years after construction completion. Solution in the uncoupled problem setting.

Thawing depth found to be $14 \mathrm{~m}$

$$
3 \alpha^{t h(f)} K^{t h(f)} T_{0} \frac{\partial}{\partial t}\left(\frac{\partial u_{i}}{\partial x_{i}}\right)
$$

of the heat propagation equation changes the value of thawed soil settlement up to $25 \%$. The effect of coupling the thermoelasticity equations intensifies with the increase in deformation exerted on the soil by the bulk and surface forces in a unit of time. Equilibrium equations of elasticity theory for the determination of soil settlement make it possible to estimate 3-dimensional soil thawing-driven deformation. In contrast, the same cannot be achieved via models employing the method of layer-by-layer addition.

\section{REFERENCES}

1. Fadeyev A.B. Finite elements method in geomechanics, Moscow, Nyedra, 1987, 224 pages (in Russian).

2. Kiselyov M.F. Compressibility theory for thawing soils under pressure. Leningrad, Stroyizdat, 1978, 174 pages (in Russian).

3. Kudryavtsev S.A., Paramonov V.N., Sakharov I.I., Shashkin A.G. Methods of finite elements applied to tasks of geotech- 
nics, Khabarovsk, DVGUPS, 2014, 162 pages (in Russian).

4. Melnikov A.V., Sakharov I.I. Parameter determination for strain-stress state of frost susceptible heaving soil in a multidimensional problem setting. // Contemporary problems of science and education, Number 1, 2013, 7 pages.

5. Novatsky V. Elasticity theory, Moscow, Mir, 1975, 872 pages (in Russian).

6. SNIP 2.02.04-88. Bases and foundations on permafrost soil, Moscow, APP TSITP, 1990 (in Russian).

7. Velli Y.Y., Dokuchayev V.V., Fyodorov N.V. Buildings and structures in the Extreme North, Leningrad, Gosstroyizdat, 1963, 492 pages (in Russian).

Roman N. Stepanov, Ph.D., Associate Professor, Department of Structural and Theoretical Mechanics, National Research Moscow State University of Civil Engineering; 26, Yaroslavskoye Shosse, Moscow, 129337, Russia; Phone +7(495)287-49-14 add. 3074;

E-mail: stroimeh@mgsu.ru

Fedor B. Kiselyov, Ph.D., Associate Professor, Department of Structural and Theoretical Mechanics, National Research Moscow State University of Civil Engineering; 26, Yaroslavskoye Shosse, Moscow, 129337, Russia; Phone +7(495)287-49-14 add. 3074;

E-mail: stroimeh@mgsu.ru

Filipp V. Sergeyev, Assistant, Department of Structural and Theoretical Mechanics, National Research Moscow State University of Civil Engineering; 26, Yaroslavskoye Shosse, Moscow, 129337, Russia;

Phone +7(495)287-49-14 add. 3074;

E-mail: stroimeh@mgsu.ru

Степанов Роман Николаевич, доцент, кандидат технических наук, доцент кафедры строительной и теоретической механики; Национальный исследовательский Московский государственный строительный университет; 129337, Россия, г. Москва, Ярославское шоссе, д. 26; тел. +7(495)287-49-14, доб. 3074;

E-mail: stroimeh@mgsu.ru

Киселев Федор Борисович, доцент, кандидат физикоматематических наук, доцент кафедры строительной и теоретической механики; Национальный исследовательский Московский государственный строительный университет; 129337, Россия, г. Москва, Ярославское шоссе, д. 26; тел. +7(495)287-49-14, доб. 3074;

E-mail: stroimeh@mgsu.ru

Сергеев Филипп Сергеевич, ассистент кафедры строительной и теоретической механики; Национальный исследовательский Московский государственный строительный университет; 129337, Россия, г. Москва, Ярославское шоссе, д. 26; тел. +7(495)287-4914, доб. 3074; E-mail: stroimeh@mgsu.ru 